\title{
ORGANOSOLUBLE XANTHONE-BASED POLYIMIDES: SYNTHESIS, CHARACTERIZATION, ANTIOXIDANT ACTIVITY AND HEAVY-METAL SORPTION
}

\author{
ORGANSKO TOPNI POLIAMIDI NA OSNOVI KSANTONA: \\ SINTEZA, KARAKTERIZACIJA, ANTIOKSIDATIVNA AKTIVNOST \\ IN SORPCIJA TEŽKIH KOVIN
}

\author{
Moslem Mansour Lakouraj ${ }^{1}$, Ghasem Rahpaima ${ }^{2}$, Razieh Azimi ${ }^{1}$ \\ ${ }^{1}$ University of Mazandaran, Faculty of Chemistry, Department of Polymer Chemistry, Babolsar, Iran \\ ${ }^{2}$ Islamic Azad University, Department of Chemistry, Lamerd Branch, Lamerd, Iran \\ lakouraj@umz.ac.ir \\ Prejem rokopisa - received: 2013-10-15; sprejem za objavo - accepted for publication: 2015-08-25
}

doi: $10.17222 /$ mit. 2013.250

\begin{abstract}
To improve the solubility, thermal properties and processability of polyxanthones, a new class of polyxanthones, poly(xanthone-imide)s (PXIs), with a high yield was prepared using a two-step chemical imidation of 2,7-diaminoxanthone with pyromellitic dianhydride (PMDA), 3,3',4,4'-benzophenone tetracarboxylic dianhydride (BTDA) and 2,2'-bis-(3,4-dicarboxyphenyl) hexafluoropropane dianhydride (6-FDA)). These PXIs were characterized with FT-IR and ${ }^{1} \mathrm{H}$ NMR spectroscopies. They presented a good solubility in aprotic polar solvents such as N,N-dimethyl acetamide (DMAc), N,N-dimethyl formamide (DMF), N-methyl pyrrolidone (NMP) and dimethyl sulfoxide (DMSO), and showed inherent viscosities in a range of $0.34-0.58$ $\mathrm{dL} / \mathrm{g}$. These PXIs exhibited lower glass-transition temperatures than the original polyxanthones and a high thermal stability. The obtained results of the UV-vis absorption and photoluminescence indicated that the maximum absorption and fluorescence emission of PXIs were in the range of 300-304 nm and 432-510 nm, respectively. The antioxidant activity of PXIs was evaluated with a DPPH assay. The antioxidant values for PXIs were greater than for the parent xanthone (X). The polyimides were investigated for the extraction of environmentally noxious metal ions such as $\mathrm{Cr}$ (VI), Co (II), $\mathrm{Ni}$ (II), Cu (II), Pb (II) and Cd (II) from aqueous solutions.

Keywords: poly(xanthone-imide)s, antioxidant activity, fluorescence, organosolubility, heavy metals
\end{abstract}

Za izboljšanje topnosti, toplotnih lastnosti in predelovalnost poliksantonov je bila pripravljena nova vrsta poliksantonov, poli(ksanton-imidov (PXIs)) z visokim izkoristkom, z uporabo dvostopenjske kemijske sinteze 2,7-diaminoksantona z piromelitnim dianhidridom (PMDA), 3,3',4,4'-benzofenon tetrakarboksiličnega dianhidrida (BTDA) in 2,2'-Bis-(3,4-Dikarbofenil) heksafluorpropan dianhidrida (6-FDA)). Ti PXI-ji so bili karakterizirani s FT-IR in ${ }^{1} \mathrm{H}$ NMR-spektroskopijo. Predstavljajo dobro topnost $\mathrm{v}$ aprotičnih polarnih topilih, kot je N,N-dimetil acetamid (DMAc), N,N-dimetil formamid (DMF), N-metil pirolidon (NMP) in dimetil sulfoksid (DMSO) in kažejo nespremenljivo viskoznost v območju $0,34-0,58 \mathrm{dL} / \mathrm{g}$. Ti PXI-ji kažejo nižjo temperaturo prehoda v steklasto stanje kot originalni poliksantoni ter veliko termično stabilnost. Dobljeni rezultati UV-absorpcije in fotoluminiscence kažejo, da je maksimalna absorpcija in emisija fluorescence PXI-jev v območju 300-304 nm, oziroma 432-510 nm. Antioksidativna aktivnost PXI-jev je bila ocenjena z DPPH preizkusom. Vrednost protioksidativnosti za PXI-je je bila večja kot pri matičnem ksantonu. Poliamidi so bili preiskovani za ekstrakcijo okoljsko škodljivih kovinskih ionov, kot so Cr (VI), Co (II), Ni (II), Cu (II), Pb (II) in Cd (II) iz vodnih raztopin.

Ključne besede: poli(ksanton-imidi), antioksidacijska aktivnost, fluorescenca, organska topnost, težke kovine

\section{INTRODUCTION}

Xanthones have a conjugated planar ring system consisting of two benzene rings bridged through a carbonyl group and an oxygen atom. This unique structure shows an admirable thermo-oxidative and hydrolytic stability with numerous potential beneficial properties such as antioxidant, ${ }^{1,2}$ antihistamine, ${ }^{3,4}$ antiinflammatory, ${ }^{5,6}$ antibacterial, ${ }^{7,8}$ antifungal, ${ }^{9}$ antiviral ${ }^{10,11}$ and anticancer ${ }^{12,13}$ effects. Consequently, it seems to have a great potential as a structural pattern in high-performance polymers. Although several different synthetic and natural xanthones were introduced ${ }^{14-18}$ few of such biologically active compounds were investigated in a polymer synthesis. ${ }^{19}$
Polyxanthones can be used for high-temperature applications and as electrical insulating materials due to their excellent solvent and chemical resistance, good physical and electrical properties even at high temperatures. However, a poor processability of the polymers is the main drawback as they have high glass or melting temperatures and are often insoluble in common organic solvents. ${ }^{20,21}$

On the other hand, due to oxidative-degradation reactions that may occur during various stages of the polymer lifecycle including the manufacturing, processing and end-use stages, it is essential to place antioxidant building block in polymer matrices. These polymers, whose antioxidant moieties are covalently attached to the backbone of a polymer, have unique advantages: they are 
non-volatile and they do not penetrate into the skin and tissue.

Aromatic polyimides are well-known high-performance polymers that have a high thermal stability, excellent mechanical and chemical properties. Due to these advantageous properties, polyimides are widely used as adhesives, films, composite matrices, coatings, membranes, and in the electronic-packaging industry. ${ }^{22-25}$

Therefore, in continuation of our ongoing work on polyxanthones ${ }^{26}$ and also in order to improve the physical properties of polyxanthones, in the present study, we attempted to insert a xanthone unit into the backbone of a polyimide to develop new organosoluble polyxanthones. For this purpose, at first, 2,7-diaminoxanthone was prepared and then used for a polymerization with pyromellitic dianhydride (PMDA), 3,3', 4,4'-benzophenone tetracarboxylic dianhydride (BTDA) and 2,2'-bis-(3,4-dicarboxyphenyl) hexafluoropropane dianhydride (6-FDA). The structures of the resulting poly(xanthone-imide)s were characterized with NMR and FT-IR spectroscopies. The physical properties of these PXIs, including their viscosity, solubility, thermal stability, morphology, and their spectroscopic properties such as ultraviolet-visible absorption and fluorescence emission were studied. In addition, PXIs were also evaluated for their antioxidant activities with a 2,2-diphenyl-1 picrylhydrazyl (DPPH) assay. Furthermore, their ability to eliminate environmentally toxic heavy-metal ions such as $\mathrm{Pb}$ (II), $\mathrm{Cd}$ (II), $\mathrm{Co}$ (II), $\mathrm{Ni}$ (II), $\mathrm{Cu}$ (II) and $\mathrm{Cr}$ (VI) were studied in aqueous media.

\section{EXPERIMENTAL WORK}

\subsection{Materials}

N-methyl-2-pyrrolidone (NMP), N,N-dimethylacetamide (DMAc), acetic anhydride and pyridine were purchased from Merck and purified with distillation under a reduced pressure over calcium hydride and stored above a $4^{\circ} \mathrm{A}$ molecular sieve. Pyromellitic dianhydride (PMDA), 3,3',4,4'-benzophenone tetracarboxylic dianhydride (BTDA) and 2,2'-bis-(3,4-dicarboxyphenyl) hexafluoropropane dianhydride (6-FDA) were dried in a vacuum oven at $110^{\circ} \mathrm{C}$ for $5 \mathrm{~h}$. All the other materials and solvents, such as DMF, pyridine and DMSO were purchased from TCI Chemical Co., Fluka Chemical Co. (Buchs, Switzerland) and Merck Chemical Co. and used as received.

\subsection{Measurements}

A Bruker Tensor 27 spectrometer (Bruker, Karlsruhe, Germany) and a 400-MHz Bruker Avance DRX spectrometer in DMSO- $\mathrm{d}_{6}$ were used for recording FT-IR, ${ }^{1} \mathrm{H}$ and ${ }^{13} \mathrm{C}$ NMR spectra, respectively Inherent viscosities $\left(h_{\text {inh }}\right)$ of the polymers were determined in NMP at $0.5 \mathrm{~g}$ per $100 \mathrm{~mL}$ concentration, with an Ubbelohde viscometer (Schott-Gerate, Hofheim, Germany) at $25^{\circ} \mathrm{C}$. A thermogravimetric analysis (TGA) was conducted with a TA Instruments TGA-50 (Shimadzu, Kyoto, Japan) in a temperature range of $50-650{ }^{\circ} \mathrm{C}$ at a heating rate of $10^{\circ} \mathrm{C} / \mathrm{min}$ under nitrogen atmosphere.

Glass-transition temperatures $\left(T_{\mathrm{g}}\right)$ of the polymers were determined with a Perkin-Elmer Pyris 6 differential scanning calorimeter at a heating rate of $10{ }^{\circ} \mathrm{C} / \mathrm{min}$ under nitrogen atmosphere. The UV-visible absorption and fluorescence emission spectra were recorded on Cecil 5000 and Perkin-Elmer LS-3B spectrophotometers in an NMP solution, respectively. X-ray powder diffraction patterns were performed at room temperature (about $25^{\circ} \mathrm{C}$ ) with an X-ray diffractometer (GBC MMA instrument) with Be-filtered $\mathrm{Cu}-K_{\alpha}(0.15418 \mathrm{~nm})$ operating at $35.4 \mathrm{kV}$ and $28 \mathrm{~mA}$. The $2 \theta$ scanning range was set between $4^{\circ}$ and $50^{\circ}$ at a scan rate of $0.05^{\circ}$ per s. The concentration of metal cations in the liquid phase was determined with an atomic-absorption instrument (BRAIC WFX-130 AA).

\subsection{Monomer synthesis}

As illustrated in Figure 1, the 2,7-dinitroxanthone (DNX) and 2,7-diaminoxanthone (DAX) were prepared according to our published article..$^{22}$

\subsection{Polymer synthesis}

The general synthetic route used to produce the PXIs was as follows. A 100-mL two-necked, round-bottomed flask equipped with a magnetic stirrer bar, nitrogen-gas inlet tube and calcium chloride drying tube was charged with $0.226 \mathrm{~g}(1.0 \mathrm{mmol})$ of diamine (DAX) and $10 \mathrm{~mL}$ of dry NMP. The mixture was stirred at room temperature for $0.5 \mathrm{~h}$. Then $1.0 \mathrm{mmol}$ of a dianhydride was added and the mixture was again stirred at room temperature for $24 \mathrm{~h}$, forming a viscous solution of a poly (amic acid) (PAA) precursor in NMP. The PAA was converted into polyimide with the chemical-imidization process. ${ }^{27}$ The chemical imidization was carried out by adding $3 \mathrm{~mL}$ of a mixture of acetic anhydride/pyridine $(6: 4, v / v)$ into the PAA solution, while stirring it at room temperature for $1 \mathrm{~h}$. Then the mixture was stirred at $130{ }^{\circ} \mathrm{C}$ for $12 \mathrm{~h}$ to yield a homogeneous solution. The polymer solution was slowly poured into methanol to form a precipitate. The precipitate was then filtered, washed thoroughly with hot methanol and dried overnight under vacuum at $80{ }^{\circ} \mathrm{C}$.

PXI-a. A yield of $97 \%$, FTIR $\left(\mathrm{KBr}, \mathrm{cm}^{-1}\right): 3020$ (aromatic $\mathrm{C}-\mathrm{H}$ stretching), $1775(\mathrm{C}=\mathrm{O}$ asymmetric stretching), $1714(\mathrm{C}=\mathrm{O}$ symmetric stretching $), 1658(\mathrm{C}=\mathrm{O}$ stretching of the carbonyl group), 1466 ( $\mathrm{C}=\mathrm{C}$ stretching), 1375 (C-N stretching), 1145 (C-O stretching). ${ }^{1} \mathrm{H}$ NMR (400 MHz, DMSO-d $)_{6}$ ) d 7.52-8.84 $(8 \mathrm{H}$, aromatic protons).

PXI-b. A yield of $96 \%$, FTIR $\left(\mathrm{KBr}, \mathrm{cm}^{-1}\right): 3050$ (aromatic C-H stretching), $1780(\mathrm{C}=\mathrm{O}$ asymmetric stretching), $1705(\mathrm{C}=\mathrm{O}$ symmetric stretching $), 1660(\mathrm{C}=\mathrm{O}$ stretching of the carbonyl group), 1470 ( $\mathrm{C}=\mathrm{C}$ stretching), 
1370 (C-N stretching), 1155 (C-O stretching). ${ }^{1} \mathrm{H}$ NMR (400 MHz, DMSO-d $)$ : d 7.61-8.52 (12 H, aromatic protons).

PXI-c. A yield of $93 \%$, FTIR $\left(\mathrm{KBr}, \mathrm{cm}^{-1}\right): 3010$ (aromatic $\mathrm{C}-\mathrm{H}$ stretching), $1785(\mathrm{C}=\mathrm{O}$ asymmetric stretching), $1755(\mathrm{C}=\mathrm{O}$ symmetric stretching), $1658(\mathrm{C}=\mathrm{O}$ stretching of the carbonyl group), 1475 ( $\mathrm{C}=\mathrm{C}$ stretching), 1385 (C-N stretching), 1140 (C-O stretching). ${ }^{1} \mathrm{H}$ NMR (DMSO-d6): d 7.29-7.79 (12H Aromatic).

\subsection{Antioxidant activities}

The antioxidant activity of the compounds (PXI-a, b and c) was determined spectrophotometrically, using a stable 2,2-diphenyl-1 picrylhydrazyl (DPPH) radical according to the already reported method, with a slight modification. ${ }^{28}$ A stock solution of the PXIs $(0.5 \mathrm{mg} / \mathrm{mL})$ was prepared in DMSO, and $50 \mu \mathrm{L}$ of the prepared PXI solution was added to $5 \mathrm{~mL}$ of a $0.004 \%$ ethanol solution of the DPPH radical. After 30 min of incubation in dark at room temperature, the absorbance was observed against a blank at $517 \mathrm{~nm}$. The assay was carried out in triplicate and the percentage of inhibition was calculated using the following formula:

$\%$ inhibition $=(\mathrm{AB}-\mathrm{AA}) / \mathrm{AB} \times 100$

where $\mathrm{AB}=$ absorption of the blank and $\mathrm{AA}=$ absorption of the test.

\subsection{Water absorption}

Two examination methods were investigated for the water-absorption capacity of poly(xanthone-imide)s. Method I: the polymer $(0.2 \mathrm{~g})$ was poured in $30 \mathrm{~mL}$ water at $25{ }^{\circ} \mathrm{C}$ for $24 \mathrm{~h}$, followed instantly by weighing. Method II: a polymer powder was boiled in water at 100 ${ }^{\circ} \mathrm{C}$ for $30 \mathrm{~min}$, and its weight difference was determined with the measurements before and after the insertion.

\subsection{Adsorption capability}

Solid-liquid extractions of Cd (II), Cu (II), Co (II) and $\mathrm{Ni}$ (II) as their chloride salts, $\mathrm{Pb}$ (II) as nitrate salt and $\mathrm{Cr}(\mathrm{VI})$ as $\mathrm{Cr}_{2} \mathrm{O}_{7}^{2-}\left(\mathrm{K}_{2} \mathrm{Cr}_{2} \mathrm{O}_{7}\right)$ were carried out either
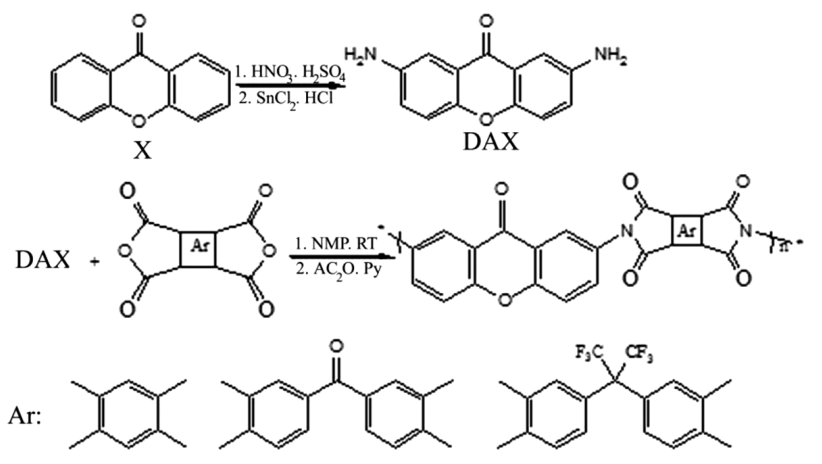

PXI- a

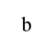

Figure 1: Synthesis and designations of poly(xanthone-imide)s (PXIs) Slika 1: Sinteza in oznaka poli(ksanton-imidov) (PXI-jev) individually or in the mixture. Approximately $10 \mathrm{mg}$ of the appropriate polymer powder was shaken with $10 \mathrm{~mL}$ of an aqueous solution of the metal salt for $3 \mathrm{~d}$ at $25^{\circ} \mathrm{C}$. The initial concentration of the salts was $10 \mathrm{mg} \mathrm{L}^{-1}$. After filtration, the concentration of each metal cation in the liquid phase was determined with the atomic-absorption technique, and direct information regarding the extraction percentage of metal ions by the polymer was obtained using a calibration curve, made for each metal ion from the standard solutions of $(5,10$, and 20$) \mu \mathrm{g} / \mathrm{g}$.

\section{RESULTS AND DISCUSSION \\ 3.1 Polyimide synthesis and characterization}

Three polyimides containing a xanthone group were prepared in high yields (90-97\%) with a polycondensation of equal molar amounts of the diamine with commercially available aromatic dianhydrides, such as PMDA, BTDA and 6-FDA, as shown in Figure 1. The polycondensation was carried out in NMP at room temperature for $24 \mathrm{~h}$ to form poly(amic acid)s, followed by chemical imidization with acetic anhydride and pyridine. The inherent viscosity of the polymers, as a suitable criterion for evaluating the molecular weight, was measured at a concentration of $0.5 \mathrm{~g} / \mathrm{dL}$ in NMP at $25{ }^{\circ} \mathrm{C}$. The inherent viscosities of the polyimides were in a range of $0.34-0.58 \mathrm{dL} / \mathrm{g}$, indicating moderate molecular weights. All the polymers were characterized using the FT-IR and ${ }^{1} \mathrm{H}$ NMR techniques. In Figure 2, the FT-IR spectrum of the PXI-b is shown as a representative polyimide. The FT-IR spectra of the PXI-b exhibited characteristic absorption bands of the five-membered imide ring at 1780 and $1705 \mathrm{~cm}^{-1}$ (typical of the imide carbonyl asymmetric and symmetric stretching), 1660 $\mathrm{cm}^{-1}$ ( $\mathrm{C}=\mathrm{O}$ stretching of the xanthone carbonyl group), $1470 \mathrm{~cm}^{-1}$ (C=C stretching), $1370 \mathrm{~cm}^{-1}$ (C-N stretching), together with a strong absorption band at $1155 \mathrm{~cm}^{-1}$ (C-O stretching). ${ }^{1} \mathrm{H}$ NMR spectra for the poly(xanthone-imide), PXI-b, is shown in Figure 3. The spectrum showed characteristic resonance signals of aromatic protons in the region of $7.61-8.52 \mu \mathrm{g} / \mathrm{g}$.

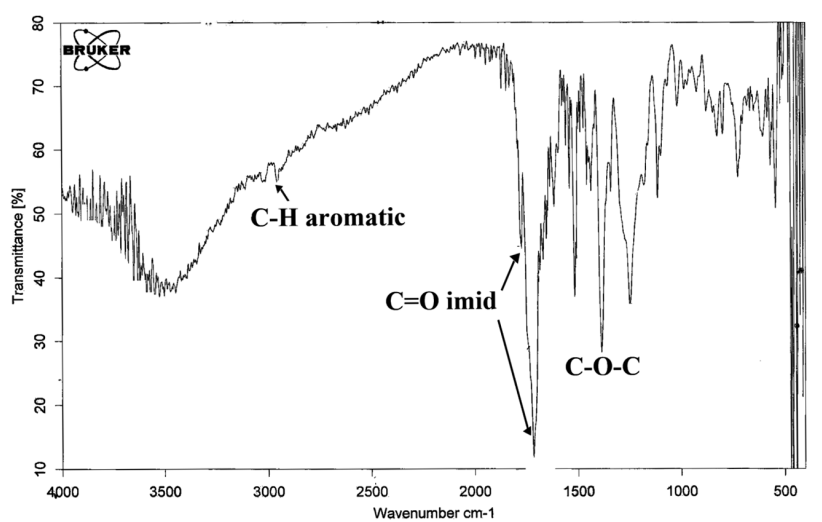

Figure 2: FT-IR spectrum of PXI-b Slika 2: FT-IR spekter PXI-b 


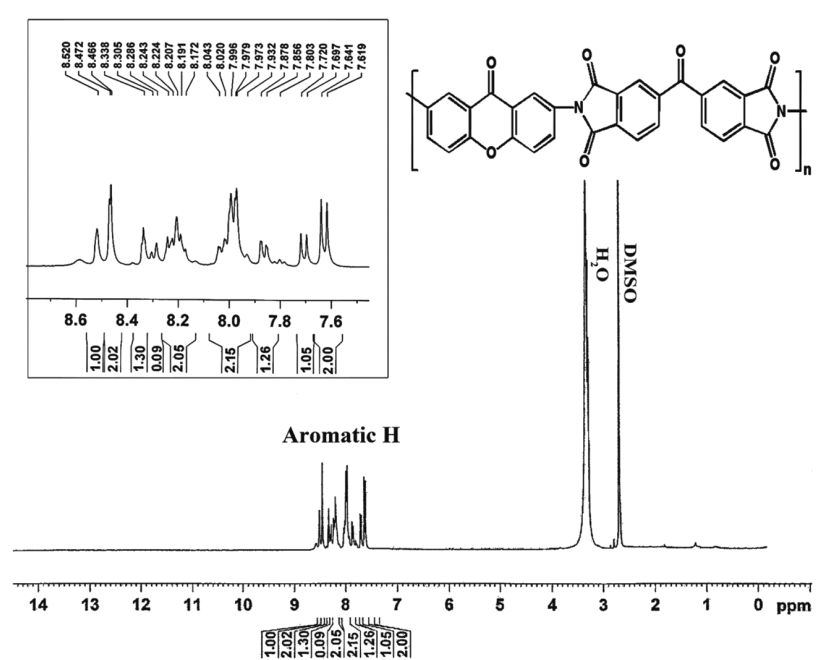

Figure 3: ${ }^{1} \mathrm{H}$ NMR spectrum of PXI-b

Slika 3: ${ }^{1} \mathrm{H}$ NMR spekter PXI-b

\subsection{Solubility and viscosity}

The solubility behavior of the poly(xanthone-imide)s depended on their chain-packing ability and intermolecular interactions, which were affected by the rigidity, symmetry and regularity of the molecular backbone. The solubility behavior of the PXIs was experienced in several organic solvents using a $5 \%(\mathrm{w} / \mathrm{v})$ concentration at room temperature, and the results are tabulated in Table 1. These poly(xanthone-imide)s had a higher solubility than the earlier reported polyxanthones. ${ }^{21}$ The solubility of these polyimides varies depending on the dianhydride used. A comparison of the solubility values for PXIs shows that the presence of carbonyl and hexafluoroisopropylidene groups in the PXI-b and PXI-c enhances their solubility at room temperature. However, the solubility of these poly(xanthone-imide)s could be improved by attaching bulky trifluoromethyl $\left(-\mathrm{CF}_{3}\right)$ groups onto the polymer chain.

The enhancement in solubility is clearly attributed to the additional effect arising from the bulky $-\mathrm{CF}_{3}$ unit, which increased the disorder in the chains, causing a less close chain packing, thus facilitating the distribution of solvent molecules among the macromolecule chains. These PXIs showed a good solubility in polar aprotic solvents such as DMF, DMAc, DMSO and NMP at room temperature, while the corresponding polyxanthone homopolymers have no solubility in such solvents at
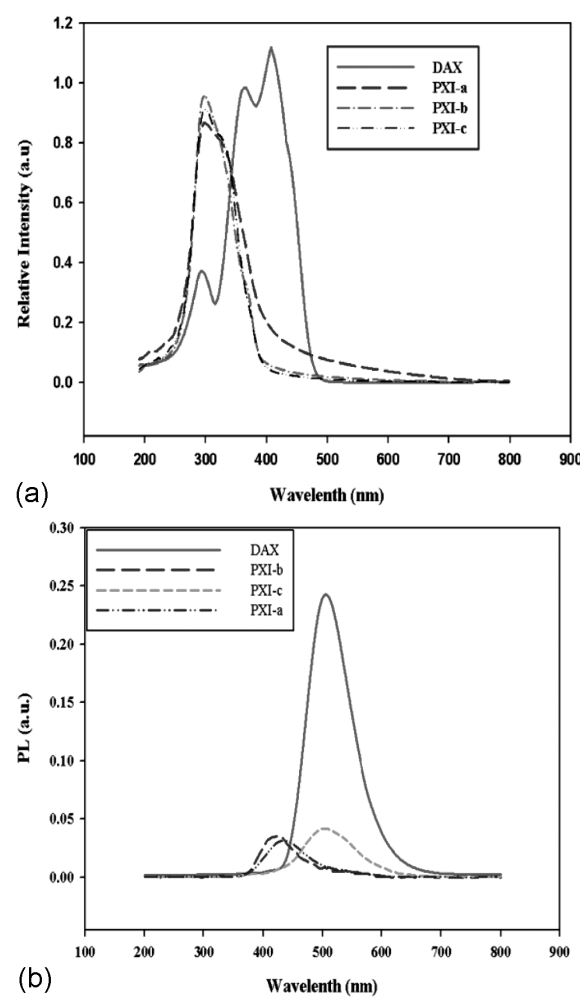

Figure 4: a) UV-vis absorption spectra and b) fluorescence emission spectra of the DAX and PXIs in NMP solution

Slika 4: a) UV absorpcijski spekter in b) emisijski spekter fluorescence DAX in PXI-jev v NMP raztopini

ambient temperature. This suggests that these polymers have potential applications in the areas such as film formation or casting process where the temperature is a determining factor.

\subsection{Optical properties}

Several classes of xanthone compounds were successfully used for protecting light-sensitive materials, controlling the harmful influence of light, especially of UV irradiation. The photophysical properties of the monomer and PXIs were examined with UV-visible and fluorescence spectroscopies in an NMP solution. The UV-vis absorption of the monomer and poly(xanthoneimide)s (Figure 4a) showed a strong absorption at 355 and 300-304 $\mathrm{nm}$, respectively, in the NMP solutions due to the $\pi-\pi^{*}$ transition of the aromatic chromophores of a xanthone ring. In comparison with the parent xanthone,

Table 1: Solubility behavior and inherent viscosities of poly(xanthone-imide)s

Tabela 1: Topnost in nespremenljiva viskoznost poli(ksanton-imidov)

\begin{tabular}{|c|c|c|c|c|c|c|c|}
\hline PXIs code & NMP & DMF & DMSO & DMAc & THF & Acetone & ETOH \\
\hline PXI-a & + & + & + & + & - & - & - \\
\hline PXI-b & ++ & ++ & ++ & ++ & - & - & - \\
\hline PXI-c & ++ & ++ & ++ & ++ & - & - & - \\
\hline
\end{tabular}

(DMAc: N,N-dimethyl acetamide; DMF: N,N-dimethyl formamide; NMP: N-methyl pyrrolidone; DMSO: dimethyl sulfoxide; THF: tetrahydrofuran; ETOH: ethanol); ++: soluble at room temperature; +: soluble during heating at $60{ }^{\circ} \mathrm{C}$; -: insoluble) 
the UV spectra of the corresponding poly(xanthoneimide)s were slightly blue shifted and broadened. The fluorescence emission spectra of the PXIs exhibited peak positions with the maxima at 413-510 $\mathrm{nm}$ (Figure 4b).

\subsection{Thermal properties}

The thermal behavior of the poly(xanthone-imide)s was evaluated with a thermogravimetric analysis (TGA) and differential scanning calorimetry (DSC) at a heating rate of $10{ }^{\circ} \mathrm{C} \mathrm{min}{ }^{-1}$ and the results obtained from these thermograms are summarized in Table 2. DSC thermograms of the polyimides are shown in Figure 5. As indicated in Figure 5, the $T_{\mathrm{g}}$ values of these PXIs are in a range of $213-285^{\circ} \mathrm{C}$, while the reported values of $T_{\mathrm{g}}$ for the bare polyxanthones were found to be higher than $370{ }^{\circ} \mathrm{C} .{ }^{21}$ The results showed that the $T_{\mathrm{g}}$ values of these PXIs depend on the structure of the dianhydride component and they decrease with the increasing flexibility of the dianhydride structure.

Table 2: Characteristic thermal data of poly(xanthone-imide)s Tabela 2: Podatki o toplotni značilnosti poli(ksanton-imidov)

\begin{tabular}{|c|c|c|c|c|}
\hline Compound & $T_{\mathrm{g}}\left({ }^{\circ} \mathrm{C}\right)$ & $T_{5}\left({ }^{\circ} \mathrm{C}\right)$ & $T_{10}\left({ }^{\circ} \mathrm{C}\right)$ & $\begin{array}{c}\text { Char. yield } \\
(\%)\end{array}$ \\
\hline PXI-a & 285 & 415 & 460 & 60 \\
\hline PXI-b & 218 & 380 & 400 & 61 \\
\hline PXI-c & 213 & 370 & 394 & 46 \\
\hline
\end{tabular}

$T_{\mathrm{g}}$ : glass-transition temperature; $T_{5}$ : temperature for a $5 \%$ weight loss $T_{10}$ : temperature for a $10 \%$ weight loss; Char. yield: weight of the polymer, kept at $700{ }^{\circ} \mathrm{C}$

The ployimide derived from PMDA exhibits the highest $T_{\mathrm{g}}$ because of a rigid backbone, while the PXI-c obtained from 6-FDA showed the lowest $T_{\mathrm{g}}$ owing to the bulky $\mathrm{CF}_{3}$ groups between the phthalimide units, which might be a result of reduced chain-to-chain charge-transfer interactions and poor chain packing of the bulky pendant $-\mathrm{CF}_{3}$ groups. Indeed, the difference in $T_{\mathrm{g}}$ of the

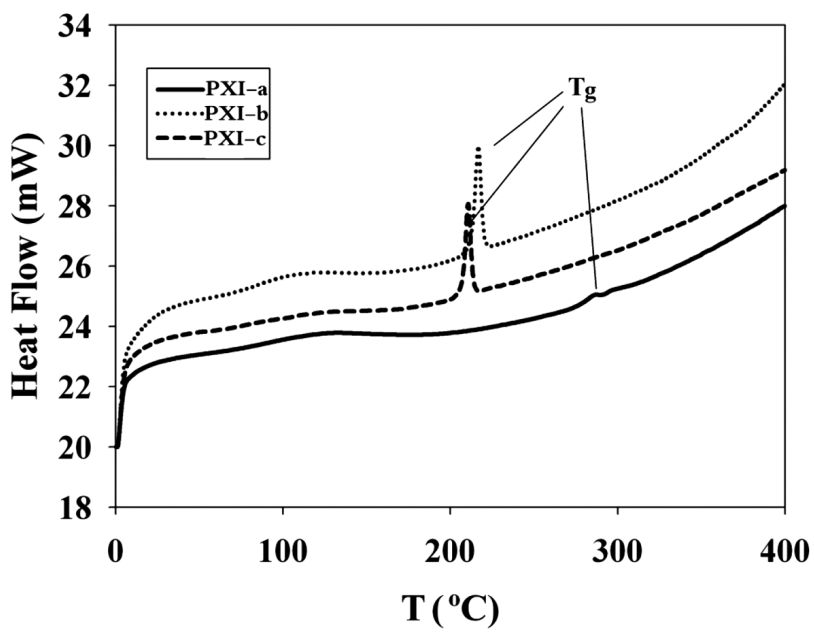

Figure 5: DSC thermograms of PXIs Slika 5: DSC-krivulja za PXI-je

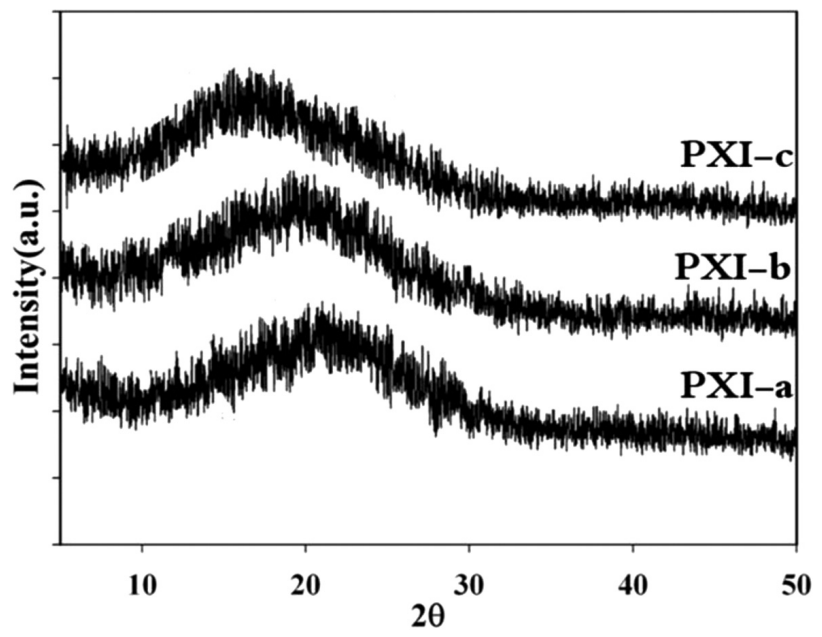

Figure 6: X-ray diffraction patterns of PXIs

Slika 6: Rentgenska difrakcija PXI-jev

PXIs can be attributed to the rigidity and close packing of the polymer chains. No melting endotherm or sign of a crystalline formation was observed in the DSC traces of the poly(xanthone-imide)s as confirmed by their WAXD patterns (Figure 6).

These observations disclose an amorphous nature of the polymers. The thermal stabilities of these poly(xanthone-imide)s were evaluated with TGA (Figure 7). The TGA data indicated a good thermal stability of the PXIs up to $460{ }^{\circ} \mathrm{C}$ with a weight loss of $10 \%$. Also, the char yields of the poly(xanthone-imide)s at $600{ }^{\circ} \mathrm{C}$ were in a range of 46-67\% implying that these polymers possess a good thermal stability. Summing up, it can be deduced that the PMDA-derived polyimide (PXI-a) has the highest thermal stability among those investigated, which can be related to the incorporation of rigid PMDA units. The introduction of hexafluoroisopropylidene units appears to reduce the packing density of molecular chains, which is strongly affected by the intermolecular interactions.

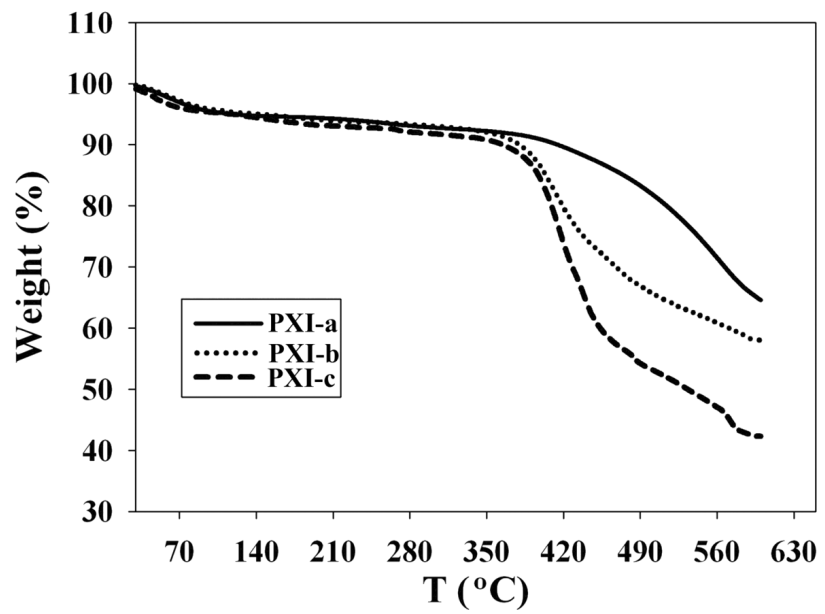

Figure 7: TGA thermograms of PXIs

Slika 7: TGA-krivulja PXI-jev 


\subsection{Antioxidant activity}

Antioxidant polymers, both externally doped and chemically bounded, are extensively utilized in the field of polymeric materials showing antioxidant properties. In recent years, this research area has grown rapidly because antioxidant polymers have many industrial applications including materials science, biomedicine, pharmaceuticals, cosmetics and food packaging. Generally, chemically bounded polymeric antioxidants have unique advantages: they are non-volatile and do not penetrate into the skin and tissue. Consequently, the use of polymeric antioxidants, in which the antioxidant species are covalently bonded to the backbone of the polymer, especially in biocompatible materials, can be a key step toward a healthy life. The antioxidant activities of the parent xanthone $(\mathrm{X})$ and PXIs were evaluated with a DPPH assay and the results are given in Table 3. The inhibition percentages determined with the DPPH assay for the monomeric diaminoxanthone was $27.07 \%$, whereas those of the PXIs were in a range of $47.80-61.30 \%$. It is evident that the polyxanthones exhibit a higher antioxidant activity than the xanthone itself. As illustrated in Figure 8, this behavior can be related to a more extended $\pi$-conjugation of the xanthone ring with imide nitrogen of poly(xanthone-imide).

Table 3: Antioxidant inhibition percentages of X and PXIs Tabela 3: Protioksidativni odstotek inhibicije $X$ in PXI-jev

\begin{tabular}{|c|c|}
\hline Compound & Inhibition percentage \\
\hline X & 27.0 \\
PXI-a & 49.4 \\
PXI-b & 61.3 \\
PXI-c & 47.8 \\
\hline
\end{tabular}

The PXI-b, obtained from BTDA, exhibited the highest antioxidant activity because of the presence of the carbonyl group between two phenyl rings, which increases the stability of radicals due to further conjugation. On the contrary, the PXI-c, obtained from 6-FDA, exhibited the lowest antioxidant activity because of the saturated carbon in the $\mathrm{C}\left(\mathrm{CF}_{3}\right)_{2}$ groups between the phthalimide units, which can effectively interrupt the conjugation. Thus, placing a xanthone unit into the polymer backbone is a simple way of preparing macromolecular systems with a high antioxidant power that may have the potential for use as biomaterials in biological media.

\subsection{Water absorption}

The water uptake affects the final application of these high-performance materials, especially in the sorption of heavy metals in water. Though the absorbed water reduces the physical properties such as the mechanical, electrical and dielectrical properties and $T_{\mathrm{g}}$, it also provides for a better presentation in the other high-tech fields such as the membrane technology. The polymers dealt with in this study have two imide groups and one xanthone moiety per repeating unit; the polar groups interact with water, which leads to partly hydrophilic materials. Two methods described in the literature ${ }^{29}$ were used for the water-absorption measurement of the PXIs: at $25{ }^{\circ} \mathrm{C}$ for $24 \mathrm{~h}$ and at $100{ }^{\circ} \mathrm{C}$ for $30 \mathrm{~min}$. As can be seen in Table 4, the PXI-b derived from BTDA showed a higher percentage of water absorption (up to $5.4 \%$ ) in comparison with the water absorption of the PXI-a and PXI-c based on PMDA and 6FDA (up to 5.0 and $4.8 \%$, respectively). This is probably due to the existence of the carbonyl group in the backbones of BTDA-based polymers.

Table 4: Water absorption of PXIs

Tabela 4: Absorpcija vode PXI-jev

\begin{tabular}{|c|c|c|}
\hline Compound & Method 1(\%) & Method 2(\%) \\
\hline PXI-a & 4.7 & 5.0 \\
PXI-b & 5.1 & 5.4 \\
PXI-c & 4.4 & 4.8 \\
\hline
\end{tabular}

\subsection{Adsorption capability}

The PXI-b (10 mg) was dissolved in $10 \mathrm{~mL}$ of an aqueous solution of heavy metals such as $\mathrm{Co}$ (II), $\mathrm{Pb}$ (II), $\mathrm{Cd}$ (II), Ni (II), $\mathrm{Cu}$ (II) and $\mathrm{Cr}$ (VI). The mixtures were agitated magnetically at reasonable $\min ^{-1}$ for $3 \mathrm{~d}$ and the solids were separated with filtration. The concentration of metal ions in the filtrate was analyzed via atomic absorption spectroscopy. The quantity of the adsorbed metal ions was calculated with the following equation:

$$
Q_{\mathrm{t}}=\left(C_{0}-C_{A}\right) \times V / w
$$

where $Q_{\mathrm{t}}$ is the amount of metal ions adsorbed into the unit of the composites $\left(\mathrm{mg} \mathrm{g}^{-1}\right), C_{0}$ and $C_{\mathrm{A}}$ are the concentrations of metal ions in the initial solution and in the aqueous phase after the adsorption, respectively $\left(\mathrm{mg} \mathrm{mL}^{-1}\right) . V$ is the volume of the aqueous phase $(\mathrm{mL})$ and $w$ is the weight of the polymer (mg). The effectiveness of the metal-ion adsorption from the solution $(\% R)$ was calculated using the following equation:

$$
R=\left(C_{i}-C_{e}\right) / C_{i} \times 100
$$

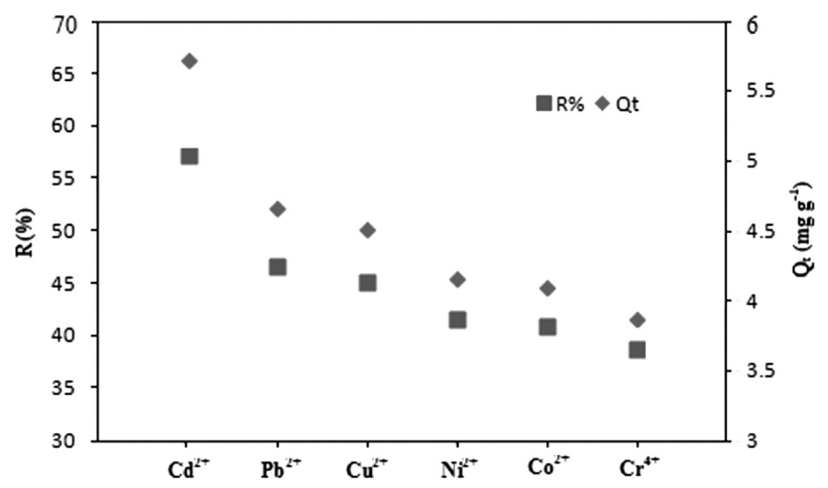

Figure 8: Sorption of transition-metal cations in water using PXIs Slika 8: Sorpcija kationov prehodnih kovin v vodi z uporabo PXI-jev 


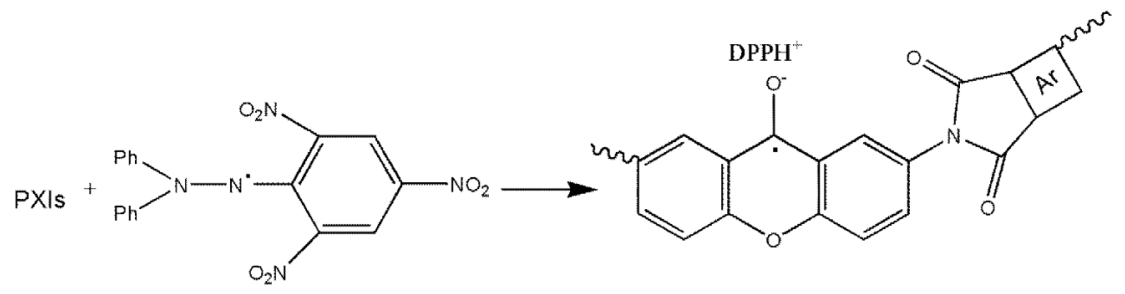

Figure 9: Proposed DPPH radical-scavenging mechanism

Slika 9: Predlagani radikalni splakovalni mehanizem DPPH

where $C_{i}$ and $C_{e}$ are the initial concentration and the concentration at the equilibrium of metal ions in the solution, respectively.

Figure 9 depicts the solid-liquid extraction results for the elimination of individual metal cations from the aqueous solution at $25^{\circ} \mathrm{C}$. As can be seen in Figure 9, both parameters, $Q_{\mathrm{t}}$ and $\% R$, increased in the order of $\mathrm{Cd}$ (II) $>\mathrm{Pb}$ (II) $>\mathrm{Cu}$ (II) $>\mathrm{Ni}$ (II) $>\mathrm{Co}$ (II) $>\mathrm{Cr}$ (VI), which is comparable with the order of their ionic radia. In Figure 9, the extraction for the smallest metal ion $\mathrm{Cr}$ (VI) is about $39 \%$ and for the largest metal ion $\mathrm{Pb}$ (II), it increases up to $47 \%$, while the extraction for Cd (II) has the highest quantity; these results were compared with those of poly(azoxanthone-esters) ${ }^{30}$ in Table 5 . Therefore, it can be suggested that the carbonyl functional groups along the polymer chains provide a coordinating site to chelate with the metal ions (Figure 10).

Table 5: Heavy-metal sorption capability (\%) of PXI-b in comparison with poly(azoxanthone-ester)

Tabela 5: Sposobnost sorpcije težkih kovin (\%) PXI-jev v primerjavi s poli(azoksanton-estra)

\begin{tabular}{|c|c|c|c|c|c|c|}
\hline Compound & $\mathrm{Cd}^{2+}$ & $\mathrm{Pb}^{2+}$ & $\mathrm{Cu}^{2+}$ & $\mathrm{Ni}^{2+}$ & $\mathrm{Co}^{2+}$ & $\mathrm{Cr}(\mathrm{VI})$ \\
\hline PAXEO & 59.7 & 48.8 & 45 & 44.2 & 43.6 & 40 \\
\hline PXI-b & 57.3 & 47 & 45.2 & 42 & 41.1 & 39 \\
\hline
\end{tabular}

\section{CONCLUSION}

A series of organosoluble poly(xanthone-imide)s with an antioxidant activity was prepared through a two-step chemical imidation of 2,7-diaminoxanthone with commercially available dianhydrides and they it was characterized using different spectroscopic techniques. These polyxanthones showed an amorphous nature with lower glass-transition temperatures $\left(T_{\mathrm{g}}\right)$ and a higher solubility than the previously reported polyxanthones. These polymers indicated inherent viscosities in a range of $0.34-0.58 \mathrm{dL} / \mathrm{g}$, showing a moderate molecular weight and being soluble in polar aprotic solvents such as DMF, NMP, DMSO and DMAc at room temperature. The $T_{10}$ values and high char yields for the poly(xanthone-imide)s indicate their good thermal stability. The introduction of a xanthone ring to the main chains of the polyimides imparts advantageous properties of the xanthone nucleus to the polyimides.

The UV-vis absorption spectra of the monomer and poly(xanthone-imide)s exhibited a strong absorption at

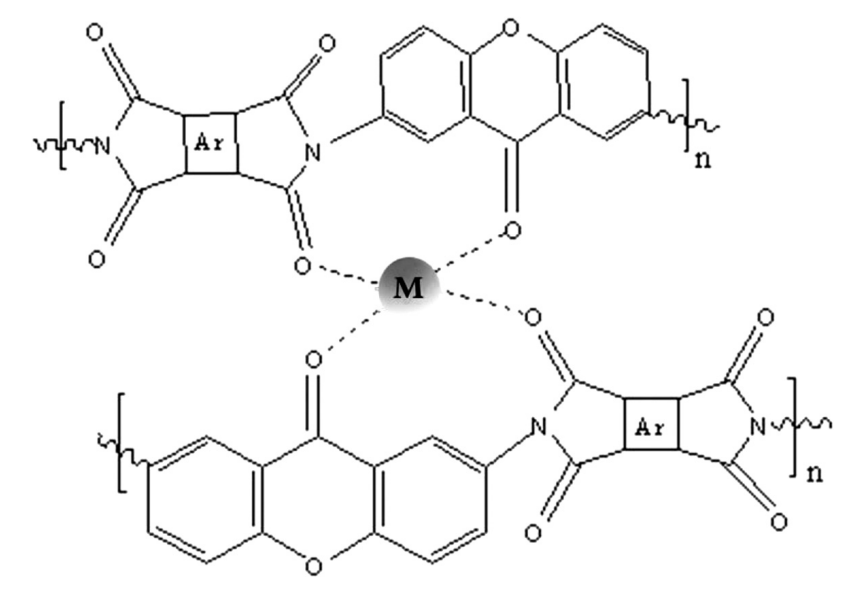

$\mathrm{M}: \mathrm{Cr}$ (VI), $\mathrm{Co}$ (II), $\mathrm{Cu}$ (II), $\mathrm{Pb}$ (II), $\mathrm{Ni}$ (II), $\mathrm{Cd}$ (II)

Figure 10: Chelation of PXIs with metal cations Slika 10: Kelacija PXI-jev s kovinskimi kationi

$355 \mathrm{~nm}$ and 300-304 nm, respectively, and the fluorescence emission spectra of the PXIs exhibited peak positions with the maxima at $413-510 \mathrm{~nm}$ in the NMP solutions.

The antioxidant capacities of the PXIs were investigated. Good antioxidant activities were obtained for all the poly(xanthone-imide)s. Interestingly, the results showed that antioxidant activities were enhanced after an insertion of xanthone into the polymeric chain.

Also, the solid-liquid extractions were carried out in an aqueous solution and the results showed that the PXIs are effective for eliminating risky heavy metals such as $\mathrm{Co}$ (II), $\mathrm{Pb}$ (II), Cd (II), Ni (II), Cu (II) and Cr (VI) from wastewaters.

Summing up, an insertion of the xanthone structure into the polymer backbone provides for a high antioxidant activity of polyxanthone imides that may have a potential for application in pharmaceutical and food industries, and also in the solid-phase extraction of environmentally risky cations.

\section{Acknowledgements}

We wish to express our gratitude to the Research Council of the University of Mazandaran for partial financial support of this work. 


\section{REFERENCES}

${ }^{1}$ M. Kondo, L. Zhang, H. Ji, Y. Kou, B. Ou, Bioavailability and Antioxidant Effects of a Xanthone-Rich Mangosteen (Garcinia mangostana) Product in Humans, Journal of Agricultural and Food Chemistry, 57 (2009), 8788-8792, doi:10.1021/jf901012

${ }^{2}$ A. Martínez, E. Hernández-Marin, A. Galano, Xanthones as antioxidants: A theoretical study on the thermodynamics and kinetics of the single electron transfer mechanism, Food and Function, 3 (2012), 442-450, doi:10.1039/C2FO10229C

${ }^{3}$ N. Chairungsrilerd, K. Furukawa, T. Ohta, S. Nozoe, Y. Ohizumi, Histaminergic and serotonergic receptor blocking substances from the medicinal plant Garcinia mangostana Linn, Planta Medica, 62 (1996), 471-472, doi:10.1055/s-2006-957943

${ }^{4}$ K. Nakatani, M. Atsumi, T. Arakawa, K. Oosawa, S. Shimura, N. Nakahata, Y. Ohizumi, Inhibitions of Histamine Release and Prostaglandin $\mathrm{E}_{2}$ Synthesis by Mangosteen, a Thai Medicinal Plant, Biological and Pharmaceutical Bulletin, 25 (2002), 1137-1141, doi:10.1248/bpb.25.1137

${ }^{5}$ S. L. Crockett, B. Poller, N. Tabanca, E. M. Pferschy-Wenzig, O. Kunert, D. E. Wedge, F. Bucar, Bioactive xanthones from the roots of Hypericum perforatum (common St John's wort), Journal of Science and Food Agriculture, 91 (2011), 428-434, doi:10.1002/jsfa.4202

${ }^{6}$ K. Nakatani, T. Yamakuni, N. Kondo, T. Arakawa, K. Oosawa, S. Shimura, H. Inoue, Y. Ohizumi, Biological Activities and Bioavailability of Mangosteen Xanthones: A Critical Review of the Current Evidence, Molecular Pharmacology, 66 (2004), 667-674, doi:10.3390/nu5083163

${ }^{7}$ Y. Sakagami, M. Iinuma, K. G. Piyasena, H. R. Dharmaratne, Antibacterial activity of alpha-mangostin against vancomycin resistant Enterococci (VRE) and synergism with antibiotics, Phytomedicine, 12 (2005), 203-208, doi:10.1016/j.phymed.2003.09.012

${ }^{8}$ G. Franklin, L. F. R. Conceição, E. Kombrink, A. C. P. Dias, Xanthone biosynthesis in Hypericum perforatum cells provides antioxidant and antimicrobial protection upon biotic stress, Phytochemistry, 70 (2009), 65-73, doi:10.1016/j.phytochem.2008.10.016

${ }^{9}$ E. Pinto, C. Afonso, S. Duarte, L. Vale-Silva, E. Costa, E. Sousa, M. Pinto, Antifungal Activity of Xanthones: Evaluation of their Effect on Ergosterol Biosynthesis by High-Performance Liquid Chromatography, Chemical Biology and Drug Design, 77 (2011), 212-222, doi:10.1111/j.1747-0285.2010.01072.x

${ }^{10}$ V. Reutrakul, N. Anantachoke, M. Pohmakotr, T. Jaipetch, S. Sophasan, C. Yoosook, J. Kasisit, C. Napaswat, T. Santisuk, P. Tuchinda, Cytotoxic and anti-HIV-1 caged xanthones from the resin and fruits of Garcinia hanburyi, Planta Medica, 73 (2007), 33-40, doi:10.1055/ s-2006-951748

${ }^{11}$ A. Groweiss, J. H. Cardellina, M. R. Boyd, HIV-Inhibitory prenylated xanthones and flavones from Maclura tinctoria, Journal of Natural Products, 63 (2000), 1537-1539, doi:10.1021/np000175m

${ }^{12}$ P. Moongkarndi, N. Kosem, O. Luanratana, S. Jongsomboonkusol, N. Pongpan, Polyphenols from the mangosteen (Garcinia mangostana) fruit for breast and prostate cancer, Fitoterapia, 75 (2004), 375-377, doi:10.3389/fphar.2013.00080

${ }^{13}$ M. K. Schwaebe, T. J. Moran, J. P. Whitten, Total synthesis of psorospermin, Tetrahedron Letters, 46 (2005), 827-829, doi:10.1016/ j.tetlet.2004.12.006

${ }^{14}$ F. M. Hauser, W. A. Dorsch, General and Expedient Synthesis of 1,4-Dioxygenated Xanthones, Organic Letters, 5 (2003), 3753-3754, doi:10.1021/ol201910v

${ }^{15}$ Z. H. Zhang, H. J. Wang, X. Q. Ren, Y. Y. Zhang, A facile and efficient method for synthesis of xanthone derivatives catalyzed by $\mathrm{HBF}_{4} / \mathrm{SiO}_{2}$ under solvent-free conditions, Monatshefte für Chemie, 140 (2009), 1481-1483, doi:10.1007/s00706-009-0204-9
${ }^{16}$ D. H. A. Rocha, D. C. G. A. Pinto, A. M. S. Silva, T. Patonay, J. A. S. Cavaleiro, A New Synthesis of 5-Arylbenzo[c]xanthones from Photoinduced Electrocyclisation and Oxidation of (E)-3-Styrylflavones, Synlett, 4 (2012), 559-564, doi:10.1055/s-0031-1290355

${ }^{17}$ J. Zhao, C. R. Larock, One-Pot Synthesis of Xanthones and Thioxanthones by the Tandem Coupling-Cyclization of Arynes and Salicylates, Organic Letters, 7 (2005), 4273-4275, doi:10.1021/ ol0517731

${ }^{18}$ S. Boonsr, C. Karalai, C. Ponglimanont, A. Kanjana-opas, K. Chantrapromma, Antibacterial and cytotoxic xanthones from the roots of Cratoxylum formosum, Phytochemistry, 67 (2006), 723-727, doi:10.1016/j.phytochem.2006.01.00

${ }^{19}$ J. L. Patel, H. S. Patel, Xanthone Polymers Derived from Salicylic Acid-Formaldehyde Polymers, Journal of Macromolecular Science Part A, 23 (1986), 285-294, doi:10.1080/00222338608063391

${ }^{20}$ R. Darms, Fairfax, Wilmington, Del., Polyxanthones, United States Patent Office, 1970, 3546167

${ }^{21}$ H. M. Colquhoun, D. F. Lewis, D. J. Williams, Synthesis of Dixanthones and Poly(dixanthone)s by Cyclization of 2-Aryloxybenzonitriles in Trifluoromethanesulfonic Acid, Organic Letters, 3 (2001), 2337-2340, doi:10.1021/o1010097+

${ }^{22}$ M. Ghaemy, M. Bazzar, Synthesis of soluble and thermally stable polyimides from 3,5-diamino- $N$-(4-(8-quinolinoxy) phenyl) aniline and various dianhydrides, Journal of Apply Polymer Science, 119 (2011), 983-988, doi:10.1002/app.32817

${ }^{23}$ S. Zhang, Y. Li, D. Yin, X. Wang, X. Zhao, Y. Shao, S. Yang, Study on synthesis and characterization of novel polyimides derived from 2,6-Bis(3-aminobenzoyl) pyridine, European Polymer Journal, 41 (2005), 1097-1107, doi:10.1016/j.eurpolymj.2004.11.014

${ }^{24}$ T. Lee, J. Lim, I. Chung, I. Kim, C. S. Ha, Preparation and characterization of polyimide/modified $\beta$-cyclodextrin nanocomposite films, Macromolecular Research, 18 (2010), 120-128, doi:10.1007/ s13233-009-0120-1

${ }^{25}$ H. S. Jin, J. H. Chang, Synthesis and Characterization of Colorless Polyimide Nanocomposite Films Containing Pendant Trifluoromethyl Groups, Macromolecular Research, 16 (2008), 503-509, doi:10.1007/BF03218551

${ }^{26}$ M. M. Lakouraj, G. Rahpaima, M. Mohseni, Synthesis, characterization, and biological activities of organosoluble and thermally stable xanthone-based polyamides, Journal of Materials Science, 48 (2013), 2520-2528, doi:10.1007/s10853-012-7041-7

${ }^{27}$ J. P. Chen, A. Natanoshn, Synthesis and characterization of novel carbazole-containing soluble polyimides, Macromolecules, 32 (1999), 3171-3177, doi:10.1021/ma981609b

${ }^{28}$ M. Kumar, K. Sharma, R. M. Samarth, A. Kumar, Synthesis and antioxidant activity of quinolinobenzothiazinones, European Journal of Medical Chemistry, 45 (2010), 4467-4472, doi:10.1016/j.ejmech. 2010.07.006

${ }^{29}$ K. Xie, S. Y. Zhang, J. G. Liu, M. H. He, S. Y. Yang, Synthesis and characterization of soluble fluorine-containing polyimides based on 1,4-bis(4-amino-2-trifluoromethylphenoxy)benzene, Journal of Polymer Science, Part A: Polymer Chemistry, 39 (2001), 2581-2590, doi:10.1002/pola.1235

${ }^{30}$ M. M. Lakouraj, G. Rahpaima, M. Mohseni, Synthesis, characterization, metal sorption, and biological activities of organosoluble and thermally stable azoxanthone-based polyester, Polymer for Advanced Technology, 26 (2015), 234-244, doi:10.1002/pat.3446 